\title{
Immunomodulation by Mesenchymal Stem Cells A Potential Therapeutic Strategy for Type 1 Diabetes
}

\section{Citation}

Abdi, Reza, Paolo Fiorina, Chaker N. Adra, Mark Atkinson, and Mohamed H. Sayegh. 2008. Immunomodulation by Mesenchymal Stem Cells A Potential Therapeutic Strategy for Type 1 Diabetes. Diabetes 57(7): 1759-1767.

\section{Published Version}

doi: $10.2337 / \mathrm{db} 08-0180$

\section{Permanent link}

http://nrs.harvard.edu/urn-3:HUL.InstRepos:8438171

\section{Terms of Use}

This article was downloaded from Harvard University's DASH repository, and is made available under the terms and conditions applicable to Other Posted Material, as set forth at http:// nrs.harvard.edu/urn-3:HUL.InstRepos:dash.current.terms-of-use\#LAA

\section{Share Your Story}

The Harvard community has made this article openly available.

Please share how this access benefits you. Submit a story.

Accessibility 


\title{
Immunomodulation by Mesenchymal Stem Cells
}

\section{A Potential Therapeutic Strategy for Type 1 Diabetes}

\author{
Reza Abdi, ${ }^{1}$ Paolo Fiorina, ${ }^{1,2}$ Chaker N. Adra, ${ }^{1,3}$ Mark Atkinson, ${ }^{4}$ and Mohamed H. Sayegh ${ }^{1,3}$
}

\begin{abstract}
Mesenchymal stem cells (MSCs) are pluripotent stromal cells that have the potential to give rise to cells of diverse lineages. Interestingly, MSCs can be found in virtually all postnatal tissues. The main criteria currently used to characterize and identify these cells are the capacity for self-renewal and differentiation into tissues of mesodermal origin, combined with a lack in expression of certain hematopoietic molecules. Because of their developmental plasticity, the notion of MSC-based therapeutic intervention has become an emerging strategy for the replacement of injured tissues. MSCs have also been noted to possess the ability to impart profound immunomodulatory effects in vivo. Indeed, some of the initial observations regarding MSC protection from tissue injury once thought mediated by tissue regeneration may, in reality, result from immunomodulation. Whereas the exact mechanisms underlying the immunomodulatory functions of MSC remain largely unknown, these cells have been exploited in a variety of clinical trials aimed at reducing the burden of immunemediated disease. This article focuses on recent advances that have broadened our understanding of the immunomodulatory properties of MSC and provides insight as to their potential for clinical use as a cell-based therapy for immune-mediated disorders and, in particular, type 1 diabetes. Diabetes 57:1759-1767, 2008
\end{abstract}

\section{WHAT ARE MESENCHYMAL STEM CELLS?}

Historical perspective, definitions, and tissue localization. More than a century ago, the presence of progenitor cells in the bone marrow with the capability of differentiating to bone were identified $(1,2)$. A series of landmark observations by Friedenstein and colleagues $(3,4)$ led to identification of the clonogenic potential of fibroblast-like cells residing in bone marrow (1). By lowdensity culturing of bone marrow on plastic culture dishes, Friedenstein and colleagues were able to discard nonadherent hematopoietic stem cells and identify plasticadherent cells or colony-forming unit fibroblasts, which were later introduced largely by Owen (5) as mesenchymal

From the ${ }^{1}$ Transplantation Research Center, Renal Division, Brigham and Women's Hospital and Children's Hospital Boston, Harvard Medical School, Boston, Massachusetts; the ${ }^{2}$ Department of Medicine, San Raffaele Scientific Institute, Milan, Italy; the ${ }^{3}$ Stem Cell Therapy Program, King Faisal Specialist Hospital and Research Centre, Riyadh, Saudi Arabia; and the ${ }^{4}$ Department of Pathology, Immunology and Laboratory Medicine, University of Florida College of Medicine, Gainesville, Florida.

Corresponding author: Reza Abdi, rabdi@rics.bwh.harvard.edu.

Received 8 February 2008 and accepted 11 April 2008.

R.A. and P.F. contributed equally to this work.

DOI: $10.2337 / \mathrm{db} 08-0180$

(C) 2008 by the American Diabetes Association. Readers may use this article as long as the work is properly cited, the use is educational and not for profit, and the work is not altered. See http://creativecommons.org/licenses/by -nc-nd/3.0/ for details.

The costs of publication of this article were defrayed in part by the payment of page charges. This article must therefore be hereby marked "advertisement" in accordance with 18 U.S.C. Section 1734 solely to indicate this fact. stromal cells. The term "mesenchymal stem cells" (MSC) appeared in the early 1980s (6) and was largely popularized by Caplan (7). Although studies highlighting the differentiation capabilities of MSC into various cell lineages including bone, cartilage, and adipose tissue have been repeatedly described over the past decade, some investigators argue that the "stemness" of MSCs is lacking, proposing instead to use the term "multipotent mesenchymal stromal cells" (8). While the acronym MSC has become the predominant term used within the literature, no matter what terminology one chooses to use, the field investigating these cells has grown rapidly because of the marked potential in terms of therapeutic exploitation.

As noted previously, MSCs are self-renewable multipotent progenitor cells that have the potential to differentiate into various lineages (9). Whereas bone marrow MSCs represent a rare population of cells that make up only 0.001 to $0.01 \%$ of total nucleated cells and are 10 -fold less abundant than hematopoietic stem cells, they can be readily grown and expanded in culture (10). The frequency of MSCs in postnatal bone marrow has been reported to decline with increasing age (11). Much of our knowledge regarding MSCs has been generated from studies using bone marrow-derived MSCs. However, the source tissue for studies of MSCs has recently been expanded to cells deriving from virtually all tissues including muscle, adipose tissue, and umbilical cord blood (12). It is important to note that the origin of MSCs may determine their fate and functional characteristics (13). Furthermore, whereas the exact functions of MSCs within tissues remain largely unknown, they appear to exert different functions in specific tissues where they reside. For instance, in bone marrow, they are reported to represent the precursor cell for stromal tissues that support hematopoiesis (14). In other tissues, upon receiving appropriate biological signals during tissue injury or inflammation, they may differentiate into specialized cells and play a pivotal role in tissue repair and/or control of inflammation in situ.

MSC characteristics and methods for their isolation. From the outset, it is important to note that there is no universally agreed upon set or specific singular marker to identify these cells. As a result, a battery of negative and positive markers is generally used to phenotypically characterize these cells. MSCs generally lack specific cell surface markers of hematopoietic cells (CD14, CD34, CD11a/LFA-1, and CD45), erythrocytes (glycophorin A), and platelet and endothelial cell adhesion molecules (CD31). They express variable levels of CD105 (SH2), CD73 (SH3/4), CD44, stromal antigen 1, and a group of other adhesion molecules and receptors including CD166 (vascular cell adhesion molecule), CD54/CD102 (intracellular adhesion molecule), and CD49 (very late antigen) (15). Finally, their ability to differentiate into several mesenchymal lineages has also been used as an identity 
TABLE 1

Markers used to characterize or extract human and murine MSCs

\begin{tabular}{lcc}
\hline & Human MSCs & Murine MSCs \\
\hline FACS markers & - & \\
CD10 & - & $+/-$ \\
CD11b & + & - \\
CD13 & ++ & $+/-$ \\
CD29 & $-/+$ & -+ \\
CD31 & - & $-/+$ \\
CD34 & ++ & ++ \\
CD44 & - & - \\
CD45 & ++ & 0 \\
CD73 & ++ & $+/-$ \\
CD90 & ++ & + \\
CD105 & ++ & + \\
CD106 & $-/+$ & - \\
CD117 & + & + \\
Stro-1 & $+/-$ & - \\
Flk-1 & - & $+/-$ \\
Sca-1 & & + \\
\hline
\end{tabular}

CD, cluster of differentiation; FACS, fluorescence-activated cell sorter; Flk-1, vascular endothelial growth factor receptor 1; Stro-1, stromal antigen 1; Sca-1, stem cell antigen 1.

marker (1). It is also important to recognize that the specificity of some of these markers vary when discussing MSC derived from humans versus mice (Table 1). To date, identification of MSCs in vivo has also been difficult and challenging.

It is interesting that since the first description of MSCs by Friedenstein et al. (3), this method for isolation has largely remained the "standard of practice," being the adherence of fibroblast-like cells (when isolating cells recovered from bone marrow) to the plastic substrate of a cell culture plate, together with a concurrent lack of adherence of marrow-derived hematopoietic cells (16). Additionally, reports exist proposing negative selection to exclude hematopoietic stem cells, or using positive selections for some of the MSC markers for the purpose of enriching MSCs (9).

\section{FUNCTIONAL ACTIVITIES OF MSCs}

Immunomodulatory properties of MSCs in vitro. The immunomodulatory properties of MSCs were initially reported in T-cell proliferation assays using one of a variety of stimuli including mitogens, CD3/CD28, and alloantigens; settings where the ability of MSCs to suppress T-cell proliferation can readily be determined $(17,18)$. Such suppression occurs irrespective of donor source, including settings in which one uses "third party" MSCs. MSCs also significantly reduce the expression of certain activation markers including CD25, CD38, and CD69 on PHA-stimulated lymphocytes (18); suppress proliferation of both $\mathrm{CD}^{+}{ }^{+}$and $\mathrm{CD}^{+}$lymphocytes; and are able to abrogate the response of memory T-cells to their antigen (19).

The immunomodulatory ability of MSCs appears to take effect before the secretion of interleukin (IL)-2, since MSC-mediated anti-proliferative effects on mitogen-stimulated peripheral blood lymphocytes can be reversed (in part) by the addition of exogenous IL-2 (17). Additional studies have noted that supernatants of MSCs were unable to suppress proliferation (15). However, using a transwell culture system with a semipermeable membrane to separate MSC from leukocytes, one effort did note an inhibitory function in terms of suppression, findings that suggest the presence of soluble factors capable of suppression (20). Among the many candidates that could represent such a soluble factor, members of the transforming growth factor superfamily (transforming growth factor- $\beta$ ), hepatic growth factors, prostaglandin E2, and IL-10 secreted by MSCs have all been found to suppress T-cell-mediated antigen responses in vitro (9). Furthermore, Meisel et al. (21) reported induction indolamine 2,3-dioxygenase expression by MSC stimulated with interferon (IFN)- $\gamma$. Thus, MSC inhibition of T-cell proliferation could also be due to a depletion of tryptophan (i.e., indolamine 2,3-dioxygenase catalyzes the conversion of tryptophan to kynurenin) and subsequent inhibition of T-cell proliferation. Inducible nitric oxide synthase and heme oxygenase-1 expressed by MSCs have also been implicated for their immunosuppressive properties $(22,23)$. It is likely that these mechanisms are not mutually exclusive and that the relative contribution of each mechanism to modulating immune responses varies in different experimental models. It is also interesting to hypothesize that immunomodulation of MSCs in different tissues may be mediated by different factors. One should note, however, that lack of standardization in isolation and culture conditions and strain-dependent variation has given rise to conflicting findings and interpretations (24).

MSC interactions with T- and B-cells, dendritic cells, and natural killer cells. In addition to the soluble factors, MSCs appear to engage themselves in several other pathways regulating T-cell function. The engagement of the inhibitory molecule programmed death 1 (PD-1) to its ligands PD-L1 and PD-L2 has also been demonstrated to be responsible for inhibition of T-cell proliferation via direct contact of MSCs and target cells, leading both to modulate the expression of different cytokine receptors and transduction molecules for cytokine signaling (25). In addition to antigen recognition through the T-cell receptor, T-cell activation requires costimulatory signals involving specific molecules on the surface of both T-cells and dendritic cells. Given the absence of surface expression of key costimulatory molecules by MSCs, it has been proposed that MSCs could also render T-cells anergic, although there is still controversy surrounding the robustness of this hypo-responsiveness (20). Finally, MSCs have been shown to increase either $\mathrm{CD} 4^{+} \mathrm{CD} 25^{+}$cells or $\mathrm{CD} 4^{+} \mathrm{CD} 25^{+} \mathrm{FoxP}^{+}$cells in different models and assays (26). Bone marrow-derived MSCs have been found to have inhibitory effects on the proliferation and IgG secretion of B-cells in BXSB mice, a model for systemic lupus erythematosus (27). When MSCs isolated from the bone marrow and B-cells extracted from the peripheral blood of healthy donors were co-cultured with different B-cell stimuli, such as anti-CD40 and anti-IL-4, B-cell proliferation and immunoglobulin production were inhibited through production of soluble factors (28).

MSCs may also regulate immune response through interacting with dendritic cells. MSCs not only could inhibit differentiation of monocytes into dendritic cells but could also inhibit dendritic cell maturation, giving rise to immature dendritic cell that could subsequently render T-cells anergic (29). MSCs have also been shown to alter the cytokine secretion profile of dendritic cells toward upregulation of regulatory cytokines such as IL-10 and downregulation of inflammatory cytokines such as IFN- $\gamma$, IL-12, and tumor necrosis factor- $\alpha$, inducing a more antiinflammatory or tolerant dendritic cell phenotype $(24,29)$.

Natural killer (NK)-MSC interactions have also been the 
6

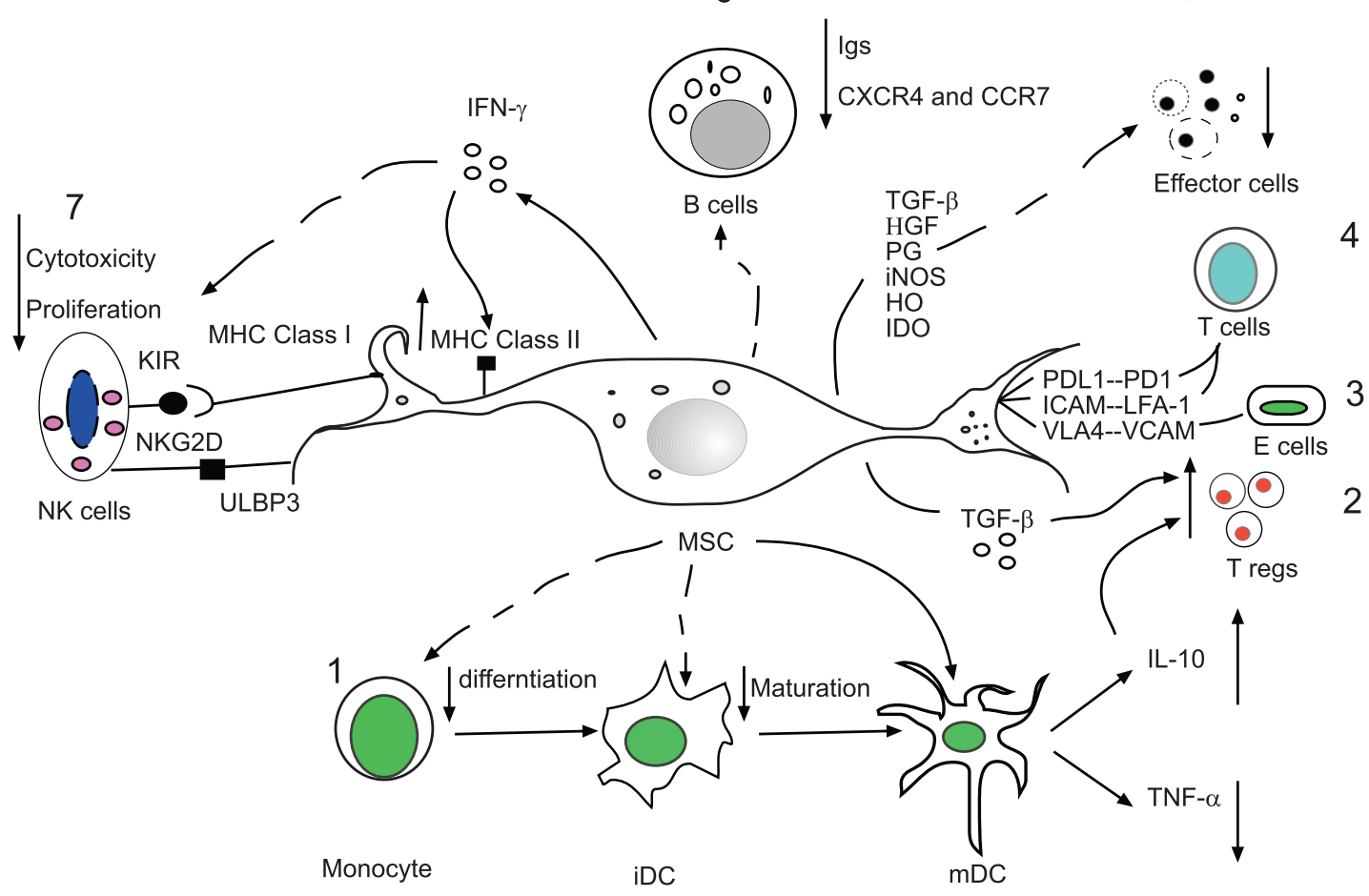

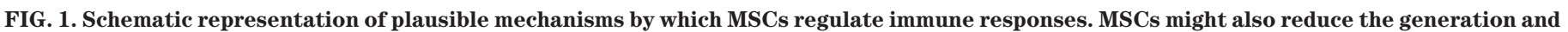

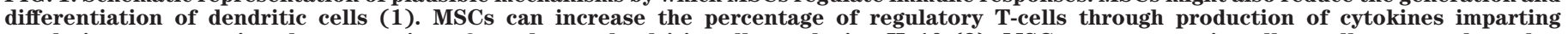

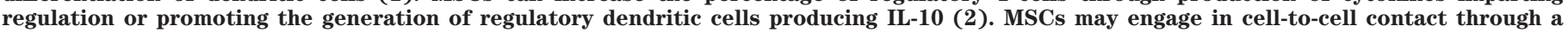

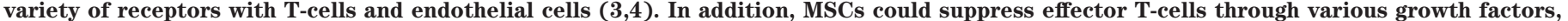

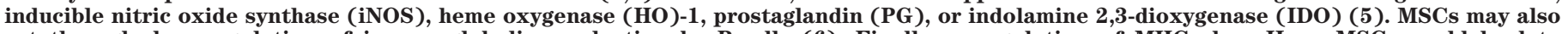

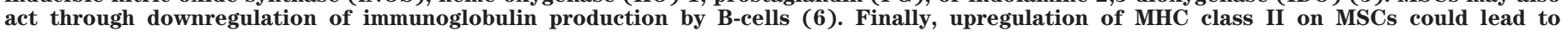

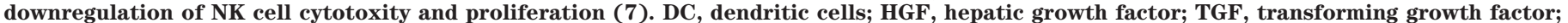
TNF, tumor necrosis factor.

subject of investigation for the purpose of understanding the mechanisms(s) of immunomodulatory action afforded by MSCs. NK cells display natural cytolytic activity against the cells that are missing markers of self-major histocompatibility complex (MHC) class I. Although initially it was thought that MSCs could escape NK cell immunosurveillance, it was recently shown that NK cells can also efficiently lyse MSCs, despite the expression of high levels of HLA-I by MSCs $(30,31)$. The NK receptors NKp30, NKG2D, and DNAM-1 were implicated in the process of NK-mediated cytotoxicity against MSCs. MSCs express the counterpart ligands for activating NK receptors $(32,33)$. However, MSCs could suppress proliferation of NK cells, decrease the secretion of IFN- $\gamma$ by IL-2-stimulated NK cells, and affect cytotoxicity against HLA class I-expressing targets. Combination effects of cell-to-cell contact and soluble factors, including transforming growth factor- $\beta 1$ and prostaglandin E2, are reported to be responsible for this observation (34).

One additional and crucial feature of MSCs is their ability to selectively migrate to sites of injury. Chemokines are increasingly being recognized as the key regulators of this preferential migration, and since MSCs express a variety of chemokine receptors and adhesion molecules (35), they are also likely to be of significance in vivo. Finally, interactions between MSCs and endothelial cells have been shown to be in part VLA-4/vascular cell adhesion molecule (VCAM) dependent (15).

MSCs and their hypo-immunogenicity. Because of the lack in expression of MHC class II and most of the classical costimulatory molecules on MSCs, these cells have historically been regarded as hypo-immunogenic cells (36). MSCs cultured with responder T-cells do not generally cause T-cell proliferation. However, recent studies suggest that MSCs are not as immunoprivileged as once thought (37).

MSCs do in fact have a large number of receptors that equip them to interact with T-cells. MHC class I and a variety of adhesion molecules, including cell adhesion molecule (CD106; VCAM), intercellular adhesion molecule 1 (ICAM-1), activated leukocyte cell adhesion molecule (CD166; ALCAM), lymphocyte functional antigen-3 (LFA3; CD58), and many other integrins on MSCs can find their counterpart ligands on T-cells (15). MHC class II is commonly reported to be absent on the surface of MSCs, but Western blotting on cell lysates has shown that the cells contain intracellular deposits of class II alloantigens $(38,39)$. Furthermore, MSCs stimulated by IFN- $\gamma$ exhibit induction of class II molecule expression (40). Because, in many inflammatory milieus, IFN- $\gamma$ is upregulated, this may increase the expression of MHC class II. Although MSCs may not induce lymphocyte activation, at least as measured through proliferation, MSCs have been shown to alter cytokine production (39). Recent studies suggest that although transplanted allogeneic MSCs can be detected in recipients for extended periods, they are recognized by the host immune response and eventually get rejected (15). Herein, we provide a summary of potential MSC immunomodulatory effects and mechanisms (Fig. 1).

MSCs and their immunomodulatory properties in vivo. Although regenerative capabilities of MSCs have been a driving force in launching initial studies testing 
TABLE 2

MSC therapy in various disease models in animals

STZ diabetes

Heart transplantation

Heart transplantation

Myocardial infarction

Acute lung injury

Chronic lung injury

Arthritis

Kidney ischemia reperfusion injury

Multiple sclerosis model (EAE)

Acute hepatic failure

GHVD

GVHD

BM transplantation
Human-MSC grafted kidney and pancreas in STZ disease

Allogenic rat-MSCs injected intravenously migrated to the heart during chronic rejection

Allogenic rat-MSCs co-injected with cyclosporine accelerate rejection

Syngeneic rat-MSCs showed an anti-inflammation role in ischemic heart disease

Syngeneic intrapulmonary murine-MSCs decrease the severity of endotoxin-induced acute lung injury and improve survival in mice

Syngeneic murine-MSCs protect lung tissue from bleomycin-induced injury with anti-inflammatory effect

Allogenic murine-MSCs reduce joint inflammation and increase Treg generation

Syngeneic murine-MSCs are helpful in the restoration of tubular epithelial cells with an anti-inflammatory effect

Syngeneic murine-MSCs are home to inflamed lymphoid tissues reducing disease progression

Human-MSCs protect against hepatocyte death and increase survival in mice after the injections of the hepatotoxin D-galactosamine

Allogenic rat-MSCs prevent lethal GVHD

Allogenic murine-MSCs did not improve GVHD

Donor-MSCs increase rejection of allogeneic donor bone marrow cells
60

Italics indicate contrasting reports. MSC were all bone marrow-derived (BM-MSC). EAE, experimental autoimmune encephalomyelitis; STZ, streptozotocin.

their therapeutic effectiveness, the immunomodulatory properties of MSCs have recently become equally exciting for investigators in terms of examining their potential implications in a variety of disease models. MSCs have been tested in rodent animal models to treat diseases where immunomodulation is thought to be the main operative mechanism (Table 2). However, it is also important to note that even in the studies focusing on the plasticity of MSCs, the benefit effects observed could also have been due to the immunomodulatory capacities of MSCs (41,42).

Notably, the MSC literature is lacking in reports on the use of MSCs in animal models of diabetes. Lee et al. (59) used immunodeficient recipient mice (NOD.SCID), chemically rendered diabetic by streptozotocin injections, to study the effect of human MSCs (hMSCs) in the development of diabetes. Infusion of hMSCs reduced glycemic levels and increased peripheral insulin levels (59). Human DNA infused as hMSCs was detected in the pancreas as well as in the kidney (59).

In pancreata from hMSC-treated diabetic mice, the islets appeared larger compared with islets from untreated diabetic mice (59). Also, the islets had an increase in mouse insulin immunoreactivity. Few human cells were detected in islets of the hMSC-treated diabetic mice by labeling sections with antibodies to human-2-microglobulin and mouse insulin (59). Kidneys from untreated diabetic mice contained many abnormal glomeruli with increased deposits of extracellular matrix protein in the mesangium (59), whereas in hMSC-treated diabetic mice, glomeruli were normal (59).
Among early reports responsible for stirring this interest was a study by Bartholomew et al. (17) in which the investigators demonstrated that donor MSC administered intravenously to MHC-mismatched recipient baboons before placement of second- and third-party skin grafts led to prolonged allograft survival. Zappia et al. (43) have also studied the immunoregulatory ability of murine MSCs to treat myelin oligodendrocyte glycoprotein-induced experimental autoimmune encephalomyelitis in C57BL/6J mice. In that effort, MSCs were injected intravenously before disease onset (i.e., preventative protocol) as well as at different time points after disease occurrence (i.e., therapeutic protocol). MSC administration before disease onset strikingly ameliorated experimental autoimmune encephalomyelitis, and overall, the therapeutic scheme was effective when MSCs were administered at disease onset as well as at the peak of disease, but not during the chronic phase. The immunoregulatory properties of MSCs interfered effectively with the autoimmune attack in the course of experimental autoimmune encephalomyelitis, inducing an in vivo state of T-cell unresponsiveness within secondary lymphoid organs. Recently, Augello et al. (44) from our group demonstrated that allogeneic murine MSCs are able to prevent tissue damage in collagen-induced arthritis, a mouse model for human rheumatoid arthritis in DBA-1 mice, and showed that MSCs exert their immunomodulatory function by educating antigen-specific regulatory $\mathrm{T}$ cells. MSCs have also been successfully used in the treatment of steroid-refractory graft versus host disease (GVHD) in both experimental animals (45) and in humans $(46,47)$. Yanez et al. (48) reported the successful control of 


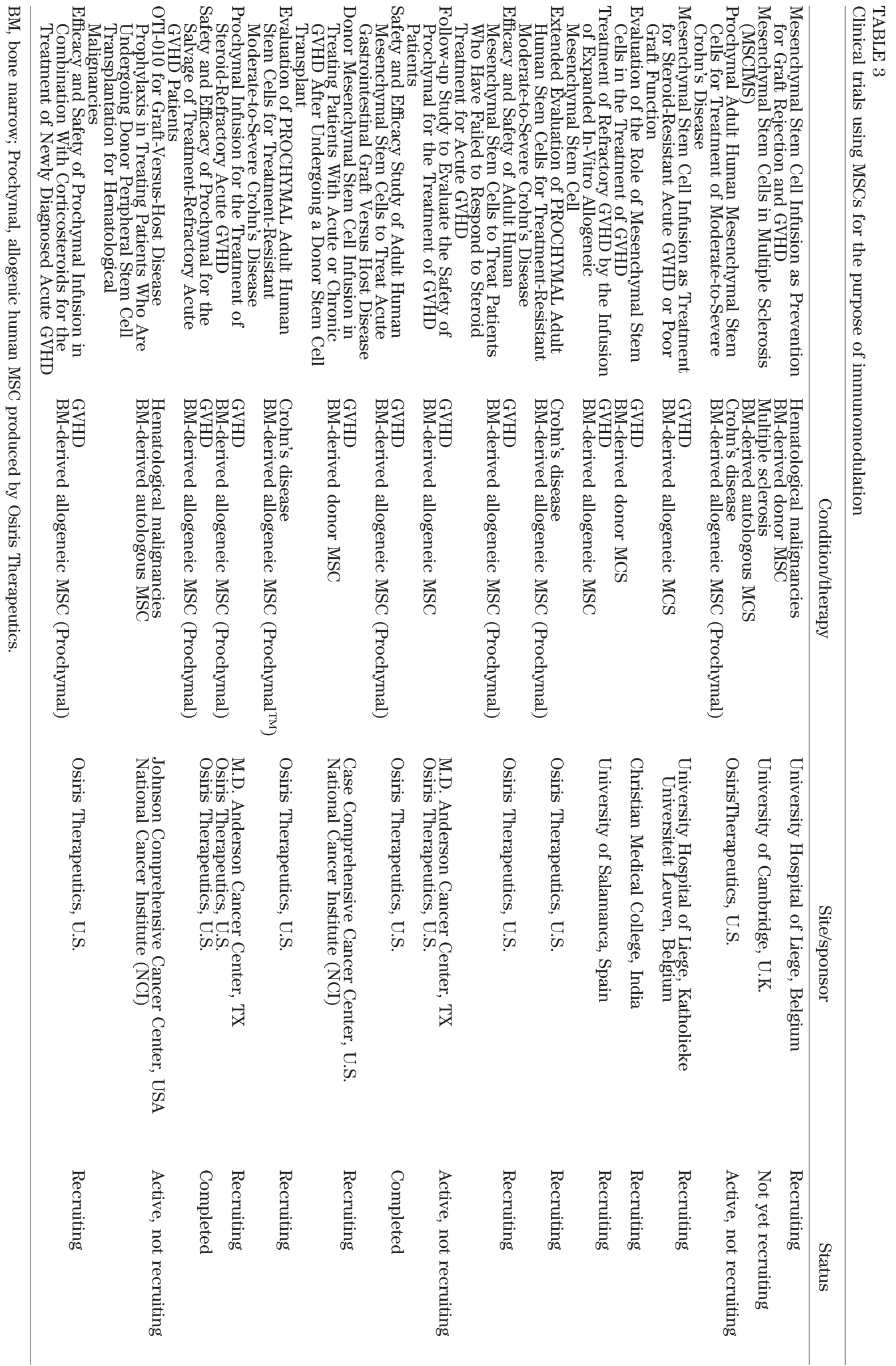


TABLE 4

Potential risks using MSCs

Safety profiling

Consideration

Cytogenetic instability of MSCs per SE and support of tumor growth

Ectopic MSC differentiation

Fetal calf serum response

Effect of inflammatory molecules released from MSC

Cell product purification

Does auto-MSC pose equal risk as allo-MSC?

Local vs. systemic administration?

Use of cocktails of growth factors or platelet lysate?

Could rejected allogeneic MSC cause systemic reactions?

Highly pure vs. mixed population?
GVHD in mice but with extraction of murine MSCs from a different cellular source (i.e., adipose tissue).

While the aforementioned studies certainly provide support for the therapeutic utility of MSCs, it should also be noted there has been contradictory data using MSCs as well. Sudres et al. (49) reported that murine MSCs were unable to ameliorate the outcome of a GVHD reaction in mice. Nauta et al. (37) examined the role of recipient and donor MSC in sublethally irradiated recipients receiving allogeneic bone marrow. Whereas the host MSCs significantly enhanced the long-term engraftment associated with tolerance to host and donor antigens, the infusion of donor MSCs significantly increased rejection of allogeneic bone marrow cells. In heart transplant models in rats, Inoue et al. (50) have shown that MSC injection not only failed to prolong allograft survival, but when MSCs were co-administered with low-dose cyclosporine, it accelerated allograft rejection.

Clinical trials using MSCs in humans. MSCs were first shown to accelerate the recovery in a patient with a severe case of GVHD (46). A limited but growing number of follow-up studies involving MSCs have been reported since, most aimed at taking advantage of the plasticity of MSCs to treat a disease. These clinical studies (Table 3) have demonstrated promising results in treating patients with cancer, in reducing the incidence of GVHD after bone marrow transplantation, in promoting heart tissue recovery from massive myocardial infarction, in improving the recovery of patients after amyotrophic lateral sclerosis, and in treating fatal disorders such as metachromatic leukodystrophy and Hurler syndrome (47,51-53). At the time of this Perspectives in Diabetes article's submission, 32 clinical trials involving administration of MSCs were listed at http://www.ClinicalTrials.gov, each potentially seeking to exploit the immunomodulatory properties of MSCs to achieve their desired therapeutic goal. In terms of type 1 diabetes, the Juvenile Diabetes Research Foundation recently announced its intent to fund the commercial entity Osiris to evaluate the immunomodulatory effects of Prochymal, a formulation of immunomodulatory adult bone marrow-derived MSCs, for the purpose of improving disease management in individuals with type 1 diabetes.

\section{FUTURE CHALLENGES FOR MSC TRIALS}

While MSC-based cell therapy is clearly promising and has been used in multiple disease scenarios with no unforeseen events (at least to date), whether any long-term complications arise from this strategy remains uncertain. As a result, many of the clinical trials are placing a high emphasis on addressing issues related to the safety of MSCs. Thus, MSC-based cell therapy still faces many hurdles, in particular addressing the safety issues, before widespread clinical applicability becomes feasible. In ad- dition to the general challenges any cell-based therapy face, there are additional issues specific to MSCs (Table 4), especially in the context of type 1 diabetes.

Standardization and quality-control studies of MSCs. Similar to stem cells, MSC characteristics and phenotype vary according to the passage cycle, culture conditions, and source of the MSCs (e.g., bone marrow, blood, cord blood, etc.). This could explain the differential outcome data that have been noted by investigators using their particular model of interest. Thus, there is a strong need to define these conditions as the field of MSC-based therapies moves forward.

In particular, a major safety issue of note is the need for fetal calf serum (FCS) to maintain MSC culture. Because FCS has been associated with transmission of diseases or undesirable immune responses to it, studies to develop and measure the safety of FCS-free culture medium are necessary. Furthermore, there is a need to define a dose range for cells and protocol of administration that result in optimal efficacy. This is particularly relevant to type 1 diabetes where, as will be discussed below, a potential exists to identify patients at increased risk for the disease and thereby allow for the development of prevention strategies; this is in addition to therapeutic protocols seeking to reverse the disorder in patients shortly after disease onset. Finally, development of refined immunologic and molecular assays capable of monitoring therapeutic efficacy must go hand in hand with planning of initial trials to make this form of therapy widely available for clinical application.

Potential tumorogenicity of MSCs. Although malignant transformation of MSCs has not been noted to date in the clinical trials using human MSCs, expansion in vitro for extended periods of time can confer risk of chromosomal instability and malignant transformation (54). It is also possible that the tendency for MSCs to undergo malignant transformation could vary according to the species (i.e., human vs. mice), source (i.e., adipose tissue vs. bone marrow), preparation, and cell cycle at the time of use. Therefore, MSCs maintained in a prolonged culture may not be risk free. Therefore, a greater understanding of MSC biology is needed to establish safe criteria for their use.

Differentiation of MSCs to unwanted tissues. The potential for MSCs to differentiate into other mesenchymal lineages (e.g., bone) could also be problematic, as was observed in the case calling for replacement of cardiac tissues (55). As noted, transformation of transplanted bone marrow material into mesodermal tissues has long been recognized (2). This is clearly an issue when MSCs are locally administered. Efforts are taken to prevent this unwanted transdifferentiation by in vivo and ex vivo stimulation of MSCs with a variety of factors (56). In the 
TABLE 5

Recommended studies to address the potential implications of MSC therapy for type 1 diabetes

Animal study designs specific to type 1 diabetes

Source of MSC

Documentation of MSC engraftment

Homing of MSC to appropriate environment

Autologous vs. allogeneic MSC

MSC passage, cell infusion number, frequency, duration, concurrent immunosuppression, and pre-injection manipulation of MSC

Monitoring of a therapeutic response
Goal

To elucidate the differential immunomodulatory properties of bone marrow, blood, and cord blood MSC

To study the life span of MSC after systemic administration

To anatomically localize MSC in lymphoid tissues and pancreas and determine their potential differentiation into islets

To study differential anti-diabetes influence of MSC from NOD, NOR and allogeneic MSC

To optimize the therapy

To develop specific in vitro assays to measure MSC anti-autoimmune properties case of systemic administration of MSC for treating autoimmunity, it is interesting to examine the value of manipulating MSCs before administration to enhance their immunomodulatory function, which could be tested in the appropriate in vitro assays. It is of value to test the idea of directing MSCs to specific lymphoid tissues where they could exert their immunomodulatory function locally where all actions take place. Therefore, there is a need for better understanding of the roles of factors that could determine their fate post-delivery.

\section{MSCS FOR THE TREATMENT OF TYPE 1 DIABETES}

Why MSCs? Despite the efforts of many, the frequency of type 1 diabetes has been steadily increasing worldwide. When taken together with the costs (both fiscal and physical) associated with the treatment of its complications, a setting has been formed where research on this disease has become priority for the field of autoimmunity. Here, the challenge involves the development of safe and effective means affording the prevention or reversal of type 1 diabetes. This would represent a remarkable accomplishment, especially when one considers that type 1 diabetes prevention studies using immunosuppressants, self-antigens, and dietary interventions (among others) have thus far demonstrated largely disappointing results (57). Indeed, even if efforts involving the aforementioned immunosuppressive agents were, over time, proven effective, the high morbidity associated with lifelong immunosuppression would remain a major limitation. As such, we and others have sought to search for other preventative measures, including MSCs. The logical question and close for this article would be to address the practical issue (with respect to MSC therapy) of why one would consider MSCs as an immune intervention for type 1 diabetes.

First, the immunological properties associated with MSCs would appear to target facets thought pathogenic for type 1 diabetes. In NOD mice, it appears that several defects in maintaining peripheral and central tolerance lead to development of autoimmune diabetes. A combination of immune cell dysfunction (including T-cell, NK cells, B-cells, and dendritic cells), as well as the presence of inflammatory cytokine milieu in a coordinated fashion, leads to this failure to maintain tolerance to $\beta$-cells (58). Furthermore, as detailed earlier in this article, MSCs possess specific immunomodulatory properties that (based on our collective knowledge of the pathogenic factors that lead to $\beta$-cell destruction in type 1 diabetes) would appear capable of disabling autoimmunity through immunomodulation. One could speculate that MSCs could regulate diabetes through a direct effect by presenting differential levels of negative costimulatory molecules and secreting regulatory cytokines such as transforming growth factor- $\beta$ and IL-10 that control regulatory T-cells/autoreactive T-cells. It is also possible that MSCs could correct the dysregulation observed at the level of B-cells and NK cells as well. Dendritic cells have been shown to be defective in NOD mice having a higher level of costimulation and having capability to shift to a Th1 type of immune response. Given the data showing interaction of MSCs with dendritic cells resulting in formation of regulatory dendritic cells, we also propose that MSCs could regulate type 1 diabetes through an indirect effect by regulating dendritic cell function. MSCs also exert anti-inflammatory effects that could be important in maintaining peripheral tolerance. Beyond this, there is the important issue of safety. While type 1 diabetes can develop in individuals at any age, it remains a disease wherein a majority of subjects are children and adolescents, individuals for whom safe interventions should be given primary consideration. This notion would be even more important were this form of therapeutic intervention applied to disease prevention in individuals considered at increased risk for type 1 diabetes (i.e., those with genetic susceptibility, autoantibodies). Finally, as discussed previously, MSCs have shown promising results in the treatment of other autoimmune disorders (e.g., experimental autoimmune encephalomyelitis and rheumatoid arthritis).

In summary, although the immunomodulatory effects of MSCs make them particularly interesting candidates for the treatment of this disease, future studies should evaluate the effect of MSCs on the prevention of and cure for type 1 diabetes through their immunomodulatory effects by examining mechanistic bases for this phenomenon first in mice and then in pilot human studies (Table 5). However, to date, the role of MSCs in type 1 diabetes remains completely unexplored. We are optimistic that future efforts in this area will shed light on the functions of MSCs as immunomodulators of the autoimmune response, providing a proof of principle to translate to clinical trials in humans. 


\section{ACKNOWLEDGMENTS}

This work was supported by Juvenile Diabetes Research Foundation grants 17-2008-368 (to M.H.S.) and 7-2006-328

(to M.A. and M.H.S.).

We thank Professor Samia J. Khoury for helpful review and suggestions.

\section{REFERENCES}

1. Prockop DJ: Marrow stromal cells as stem cells for nonhematopoietic tissues. Science 276:71-74, 1997

2. Dennis JE, AIC: Stem Cells Handbook. Totowa, NJ, Human Press, 2004

3. Friedenstein AJ, Piatetzky S II, Petrakova KV: Osteogenesis in transplants of bone marrow cells. J Embryol Exp Morphol 16:381-390, 1966

4. Friedenstein AJ, Petrakova KV, Kurolesova AI, Frolova GP: Heterotopic of bone marrow: analysis of precursor cells for osteogenic and hematopoietic tissues. Transplantation 6:230-247, 1968

5. Owen M: Marrow stromal stem cells. J Cell Sci Suppl 10:63-76, 1988

6. Sale GE, Storb R: Bilateral diffuse pulmonary ectopic ossification after marrow allograft in a dog: evidence for allotransplantation of hemopoietic and mesenchymal stem cells. Exp Hematol 11:961-966, 1983

7. Caplan AI: Mesenchymal stem cells. J Orthop Res 9:641-650, 1991

8. Horwitz EM, Le Blanc K, Dominici M, Mueller I, Slaper-Cortenbach I, Marini FC, Deans RJ, Krause DS, Keating A: Clarification of the nomenclature for MSC: The International Society for Cellular Therapy position statement. Cytotherapy 7:393-395, 2005

9. Tyndall A, Walker UA, Cope A, Dazzi F, De Bari C, Fibbe W, Guiducci S, Jones S, Jorgensen C, Le Blanc K, Luyten F, McGonagle D, Martin I, Bocelli-Tyndall C, Pennesi G, Pistoia V, Pitzalis C, Uccelli A, Wulffraat N, Feldmann M: Immunomodulatory properties of mesenchymal stem cells: a review based on an interdisciplinary meeting held at the Kennedy Institute of Rheumatology Division, London, UK, 31 October 2005. Arthritis Res Ther 9:301, 2007

10. Pittenger MF, Martin BJ: Mesenchymal stem cells and their potential as cardiac therapeutics. Circ Res 95:9-20, 2004

11. Fibbe WE: Mesenchymal stem cells: a potential source for skeletal repair. Ann Rheum Dis 61 Suppl. 2:ii29-ii31, 2002

12. da Silva Meirelles L, Chagastelles PC, Nardi NB: Mesenchymal stem cells reside in virtually all post-natal organs and tissues. J Cell Sci 119:22042213,2006

13. Keyser KA, Beagles KE, Kiem HP: Comparison of mesenchymal stem cells from different tissues to suppress T-cell activation. Cell Transplant 16:555-562, 2007

14. Sugiyama T, Kohara H, Noda M, Nagasawa T: Maintenance of the hematopoietic stem cell pool by CXCL12-CXCR4 chemokine signaling in bone marrow stromal cell niches. Immunity 25:977-988, 2006

15. Chamberlain G, Fox J, Ashton B, Middleton J: Concise review: mesenchymal stem cells: their phenotype, differentiation capacity, immunological features, and potential for homing. Stem Cells 25:2739-2749, 2007

16. Pittenger MF, Mackay AM, Beck SC, Jaiswal RK, Douglas R, Mosca JD, Moorman MA, Simonetti DW, Craig S, Marshak DR: Multilineage potential of adult human mesenchymal stem cells. Science 284:143-147, 1999

17. Bartholomew A, Sturgeon C, Siatskas M, Ferrer K, McIntosh K, Patil S, Hardy W, Devine S, Ucker D, Deans R, Moseley A, Hoffman R: Mesenchymal stem cells suppress lymphocyte proliferation in vitro and prolong skin graft survival in vivo. Exp Hematol 30:42-48, 2002

18. Le Blanc K, Tammik L, Sundberg B, Haynesworth SE, Ringden O: Mesenchymal stem cells inhibit and stimulate mixed lymphocyte cultures and mitogenic responses independently of the major histocompatibility complex. Scand J Immunol 57:11-20, 2003

19. Krampera M, Glennie S, Dyson J, Scott D, Laylor R, Simpson E, Dazzi F: Bone marrow mesenchymal stem cells inhibit the response of naive and memory antigen-specific T cells to their cognate peptide. Blood 101:37223729,2003

20. Nauta AJ, Fibbe WE: Immunomodulatory properties of mesenchymal stromal cells. Blood 110:3499-3506, 2007

21. Meisel R, Zibert A, Laryea M, Gobel U, Daubener W, Dilloo D: Human bone marrow stromal cells inhibit allogeneic T-cell responses by indoleamine 2,3-dioxygenase-mediated tryptophan degradation. Blood 103:4619-4621, 2004

22. Sato K, Ozaki K, Oh I, Meguro A, Hatanaka K, Nagai T, Muroi K, Ozawa K: Nitric oxide plays a critical role in suppression of T-cell proliferation by mesenchymal stem cells. Blood 109:228-234, 2007

23. Chabannes D, Hill M, Merieau E, Rossignol J, Brion R, Soulillou JP, Anegon I, Cuturi MC: A role for heme oxygenase-1 in the immunosuppressive effect of adult rat and human mesenchymal stem cells. Blood 110:3691-3694, 2007

24. Ryan JM, Barry FP, Murphy JM, Mahon BP: Mesenchymal stem cells avoid allogeneic rejection. J Inflamm (Lond) 2:8, 2005

25. Augello A, Tasso R, Negrini SM, Amateis A, Indiveri F, Cancedda R, Pennesi G: Bone marrow mesenchymal progenitor cells inhibit lymphocyte proliferation by activation of the programmed death 1 pathway. Eur J Immunol 35:1482-1490, 2005

26. Selmani Z, Naji A, Zidi I, Favier B, Gaiffe E, Obert L, Borg C, Saas P, Tiberghien P, Rouas-Freiss N, Carosella ED, Deschaseaux F: Human leukocyte antigen-G5 secretion by human mesenchymal stem cells is required to suppress $\mathrm{T}$ lymphocyte and natural killer function and to induce CD4+CD25highFOXP3+ regulatory T cells. Stem Cells 26:212-222, 2008

27. Deng W, Han Q, Liao L, You S, Deng H, Zhao RC: Effects of allogeneic bone marrow-derived mesenchymal stem cells on $\mathrm{T}$ and $\mathrm{B}$ lymphocytes from BXSB mice. DNA Cell Biol 24:458-463, 2005

28. Corcione A, Benvenuto F, Ferretti E, Giunti D, Cappiello V, Cazzanti F, Risso M, Gualandi F, Mancardi GL, Pistoia V, Uccelli A: Human mesenchymal stem cells modulate B-cell functions. Blood 107:367-372, 2006

29. Nauta AJ, Kruisselbrink AB, Lurvink E, Willemze R, Fibbe WE: Mesenchymal stem cells inhibit generation and function of both CD34+-derived and monocyte-derived dendritic cells. J Immunol 177:2080-2087, 2006

30. Rasmusson I, Ringden O, Sundberg B, Le Blanc K: Mesenchymal stem cells inhibit the formation of cytotoxic $\mathrm{T}$ lymphocytes, but not activated cytotoxic T lymphocytes or natural killer cells. Transplantation 76:12081213,2003

31. Krampera M, Cosmi L, Angeli R, Pasini A, Liotta F, Andreini A, Santarlasci V, Mazzinghi B, Pizzolo G, Vinante F, Romagnani P, Maggi E, Romagnani S, Annunziato F: Role for interferon-gamma in the immunomodulatory activity of human bone marrow mesenchymal stem cells. Stem Cells 24:386398, 2006

32. Poggi A, Prevosto C, Massaro AM, Negrini S, Urbani S, Pierri I, Saccardi R, Gobbi M, Zocchi MR: Interaction between human NK cells and bone marrow stromal cells induces NK cell triggering: role of NKp30 and NKG2D receptors. J Immunol 175:6352-6360, 2005

33. Spaggiari GM, Capobianco A, Abdelrazik H, Becchetti F, Mingari MC, Moretta L: Mesenchymal stem cells inhibit natural killer cell proliferation, cytotoxicity and cytokine production: role of indoleamine 2,3-dioxygenase and prostaglandin E2. Blood 111:1327-1333, 2008

34. Sotiropoulou PA, Perez SA, Gritzapis AD, Baxevanis CN, Papamichail M: Interactions between human mesenchymal stem cells and natural killer cells. Stem Cells 24:74-85, 2006

35. Fox JM, Chamberlain G, Ashton BA, Middleton J: Recent advances into the understanding of mesenchymal stem cell trafficking. $\mathrm{Br} \mathrm{J}$ Haematol 137:491-502, 2007

36. Tse WT, Pendleton JD, Beyer WM, Egalka MC, Guinan EC: Suppression of allogeneic T-cell proliferation by human marrow stromal cells: implications in transplantation. Transplantation 75:389-397, 2003

37. Nauta AJ, Westerhuis G, Kruisselbrink AB, Lurvink EG, Willemze R, Fibbe WE: Donor-derived mesenchymal stem cells are immunogenic in an allogeneic host and stimulate donor graft rejection in a nonmyeloablative setting. Blood 108:2114-2120, 2006

38. Le Blanc K, Tammik C, Rosendahl K, Zetterberg E, Ringden O: HLA expression and immunologic properties of differentiated and undifferentiated mesenchymal stem cells. Exp Hematol 31:890-896, 2003

39. Klyushnenkova E, Mosca JD, Zernetkina V, Majumdar MK, Beggs KJ, Simonetti DW, Deans RJ, McIntosh KR: T cell responses to allogeneic human mesenchymal stem cells: immunogenicity, tolerance, and suppression. J Biomed Sci 12:47-57, 2005

40. Le Blanc K, Ringden O: Immunomodulation by mesenchymal stem cells and clinical experience. J Intern Med 262:509-525, 2007

41. Morigi M, Imberti B, Zoja C, Corna D, Tomasoni S, Abbate M, Rottoli D, Angioletti S, Benigni A, Perico N, Alison M, Remuzzi G: Mesenchymal stem cells are renotropic, helping to repair the kidney and improve function in acute renal failure. J Am Soc Nephrol 15:1794-1804, 2004

42. Duffield JS, Park KM, Hsiao LL, Kelley VR, Scadden DT, Ichimura T, Bonventre JV: Restoration of tubular epithelial cells during repair of the postischemic kidney occurs independently of bone marrow-derived stem cells. J Clin Invest 115:1743-1755, 2005

43. Zappia E, Casazza S, Pedemonte E, Benvenuto F, Bonanni I, Gerdoni E, Giunti D, Ceravolo A, Cazzanti F, Frassoni F, Mancardi G, Uccelli A: Mesenchymal stem cells ameliorate experimental autoimmune encephalomyelitis inducing T-cell anergy. Blood 106:1755-1761, 2005

44. Augello A, Tasso R, Negrini SM, Cancedda R, Pennesi G: Cell Therapy Using Allogeneic Bone Marrow Mesenchymal Stem Cells Prevents Tissue 
Damage in Collagen-Induced Arthritis. Arthritis \& Rheumatism 56:11751186, 2007

45. Itakura S, Asari S, Rawson J, Ito T, Todorov I, Liu CP, Sasaki N, Kandeel F, Mullen Y: Mesenchymal stem cells facilitate the induction of mixed hematopoietic chimerism and islet allograft tolerance without GVHD in the rat. Am J Transplant 7:336-346, 2007

46. Le Blanc K, Rasmusson I, Sundberg B, Gotherstrom C, Hassan M, Uzunel M, Ringden O: Treatment of severe acute graft-versus-host disease with third party haploidentical mesenchymal stem cells. Lancet 363:1439-1441, 2004

47. Ringden O, Uzunel M, Rasmusson I, Remberger M, Sundberg B, Lonnies H, Marschall HU, Dlugosz A, Szakos A, Hassan Z, Omazic B, Aschan J, Barkholt L, Le Blanc K: Mesenchymal stem cells for treatment of therapyresistant graft-versus-host disease. Transplantation 81:1390-1397, 2006

48. Yanez R, Lamana ML, Garcia-Castro J, Colmenero I, Ramirez M, Bueren JA: Adipose tissue-derived mesenchymal stem cells have in vivo immunosuppressive properties applicable for the control of the graft-versus-host disease. Stem Cells Dev 24:2582-2591, 2006

49. Sudres M, Norol F, Trenado A, Gregoire S, Charlotte F, Levacher B, Lataillade JJ, Bourin P, Holy X, Vernant JP, Klatzmann D, Cohen JL: Bone marrow mesenchymal stem cells suppress lymphocyte proliferation in vitro but fail to prevent graft-versus-host disease in mice. $J$ Immunol 176:7761-7767, 2006

50. Inoue S, Popp FC, Koehl GE, Piso P, Schlitt HJ, Geissler EK, Dahlke MH: Immunomodulatory effects of mesenchymal stem cells in a rat organ transplant model. Transplantation 81:1589-1595, 2006

51. Mazzini L, Mareschi K, Ferrero I, Vassallo E, Oliveri G, Boccaletti R, Testa L, Livigni S, Fagioli F: Autologous mesenchymal stem cells: clinical applications in amyotrophic lateral sclerosis. Neurol Res 28:523-526, 2006

52. Koc ON, Day J, Nieder M, Gerson SL, Lazarus HM, Krivit W: Allogeneic mesenchymal stem cell infusion for treatment of metachromatic leukodystrophy (MLD) and Hurler syndrome (MPS-IH). Bone Marrow Transplant 30:215-222, 2002

53. Numaguchi Y, Sone T, Okumura K, Ishii M, Morita Y, Kubota R, Yokouchi $\mathrm{K}$, Imai H, Harada M, Osanai H, Kondo T, Murohara T: The impact of the capability of circulating progenitor cell to differentiate on myocardial salvage in patients with primary acute myocardial infarction. Circulation 114:I114-I119, 2006

54. Tolar J, Nauta AJ, Osborn MJ, Panoskaltsis Mortari A, McElmurry RT, Bell S, Xia L, Zhou N, Riddle M, Schroeder TM, Westendorf JJ, McIvor RS, Hogendoorn PC, Szuhai K, Oseth L, Hirsch B, Yant SR, Kay MA, Peister A,
Prockop DJ, Fibbe WE, Blazar BR: Sarcoma derived from cultured mesenchymal stem cells. Stem Cells 25:371-379, 2007

55. Breitbach M, Bostani T, Roell W, Xia Y, Dewald O, Nygren JM, Fries JW, Tiemann K, Bohlen H, Hescheler J, Welz A, Bloch W, Jacobsen SE, Fleischmann BK: Potential risks of bone marrow cell transplantation into infarcted hearts. Blood 110:1362-1369, 2007

56. Atsma DE, Fibbe WE, Rabelink TJ: Opportunities and challenges for mesenchymal stem cell-mediated heart repair. Curr Opin Lipidol 18:645649, 2007

57. Schatz D, Gale EA, Atkinson MA: Why can't we prevent type 1 diabetes? Maybe it's time to try a different combination. Diabetes Care 26:3326-3328, 2003

58. Anderson MS, Bluestone JA: The NOD mouse: a model of immune dysregulation. Annu Rev Immunol 23:447-485, 2005

59. Lee RH, Seo MJ, Reger RL, Spees JL, Pulin AA, Olson SD, Prockop DJ: Multipotent stromal cells from human marrow home to and promote repair of pancreatic islets and renal glomeruli in diabetic NOD/scid mice. Proc Natl Acad Sci U S A 103:17438-17443, 2006

60. Wu GD, Nolta JA, Jin YS, Barr ML, Yu H, Starnes VA, Cramer DV: Migration of mesenchymal stem cells to heart allografts during chronic rejection. Transplantation 75:679-685, 2003

61. Guo J, Lin GS, Bao CY, Hu ZM, Hu MY: Anti-inflammation role for mesenchymal stem cells transplantation in myocardial infarction. Inflammation 30:97-104, 2007

62. Gupta N, Su X, Popov B, Lee JW, Serikov V, Matthay MA: Intrapulmonary delivery of bone marrow-derived mesenchymal stem cells improves survival and attenuates endotoxin-induced acute lung injury in mice. $J$ Immunol 179:1855-1863, 2007

63. Ortiz LA, Dutreil M, Fattman C, Pandey AC, Torres G, Go K, Phinney DG: Interleukin 1 receptor antagonist mediates the antiinflammatory and antifibrotic effect of mesenchymal stem cells during lung injury. Proc Natl Acad Sci U S A 104:11002-11007, 2007

64. Gerdoni E, Gallo B, Casazza S, Musio S, Bonanni I, Pedemonte E, Mantegazza R, Frassoni F, Mancardi G, Pedotti R, Uccelli A: Mesenchymal stem cells effectively modulate pathogenic immune response in experimental autoimmune encephalomyelitis. Ann Neurol 61:219-227, 2007

65. Parekkadan B, van Poll D, Suganuma K, Carter EA, Berthiaume F, Tilles AW, Yarmush ML: Mesenchymal stem cell-derived molecules reverse fulminant hepatic failure. PLoS ONE 2: e941, 2007

66. Ikehara S: A novel strategy for allogeneic stem cell transplantation: perfusion method plus intra-bone marrow injection of stem cells. Exp Hematol 31:1142-1146, 2003 